\title{
Ocena dekohezji łopatki turbiny gazowej metodą tomografii komputerowej
}

\section{Evaluation of the decohesion effect on gas turbine blades with use of computer tomography}

\section{Streszczenie}

W procesie eksploatacji lotniczych silników turbinowych podstawową metodą diagnozowania stanu łopatek wirnikowych jest metoda wizualna (wideoendoskopowa), a wyniki potwierdza się badaniami metalograficznymi, metodą niszczącą. W artykule omówiono metodę - rentgenowską tomografię komputerową (CT) oraz możliwości jej stosowania do diagnozowania zmian stanu łopatek turbin gazowych, jako metodę badań nieniszczących (NDT). Tomografia jest transmisyjną techniką diagnostyczną umożliwiającą uzyskiwanie warstwowych obrazów detalu. Jest ona wykorzystywana w laboratoriach naukowo-badawczych i stosowana w procesie kontroli jakości produkcji.

W artykule przedstawiono wyniki badań oceny stanu eksploatowanych łopatek turbiny gazowej metodą wizualną oraz rentgenowską tomografią komputerową. Wyniki te zweryfikowano badaniami metodą metalograficzną. Stwierdzono, że metoda radiograficzna, wygenerowując przestrzenny obraz wnętrza łopatek, umożliwia rozpoznanie rodzaju wad, ich wielkości i umiejscowienia. Ponadto zaprezentowano możliwości techniczne tomografu V/tome/x m o mocy lampy 300 kV oraz możliwości obróbki danych w programie do rekonstrukcji VG Studio Max2. Równolegle prowadzone są prace z lampą do nanotomografii o mocy $180 \mathrm{kV}$ i rozdzielczości do $0,5 \mu \mathrm{m}$, szczególnie przydatną do badań materiałów kompozytowych.

Mgr inż. Marek Halimoniuk, mgr inż. Artur Kułaszka - Instytut Techniczny Wojsk Lotniczych, Warszawa.

\section{Abstract}

The basic diagnostic method usually applied to assess technical condition of rotor blades is the visual inspection carried out with use of a video endoscope. The outcome of such an inspection is validated by means of destructive tests by investigation of metallographic polished specimen. This paper outlines the innovative technique of Computer Tomography (CT) and presents its applicability and diagnostic advantages when the method is used for Non-Destructive Tests (NDT) aimed at determination how much blades of gas turbines are deteriorated due to the effect of the operational environment.

The method is used by research and scientific laboratories as well as in other fields, including quality control at manufacturing plants.

The paper compares results for evaluation of technical condition demonstrated by gas turbine blades and acquired from visual inspections against the ones from investigations by means of Computer Tomography. Finally, the results were validated by investigation of metallographic microsections. It was found out that the X-ray method is capable of producing 3D images for inner spaces of blades and thus enables identification of defect types, their sizes and locations. In addition, the paper presents technical performances of the V/tome/xm tomography with the X-ray tube for $300 \mathrm{kV}$ voltage and capabilities of the VG Studio Max2 software designed for reconstructions of images. In parallel, investigations with the use of a tube for nanotomography for the voltage of $180 \mathrm{kV}$ and resolution of $0.5 \mu \mathrm{m}$ are also in progress since that type of tube is particularly useful for investigation of composite materials.

\section{Wstęp}

W procesie eksploatacji statków powietrznych występują różnego rodzaju uszkodzenia ich napędów. Skutkuje to bezpośrednio demontażem silnika, a co za tym idzie, wycofaniem statku powietrznego z eksploatacji i bardzo dużymi kosztami [1, 2]. 
Odstępstwa od jakości produkcji i napraw stanowia dużą grupę uszkodzeń eksploatacyjnych wykrywanych w przestrzeni wewnętrznej silników lotniczych podczas przeglądów endoskopowych. Użytkownik nie ma na nie wpływu. Uszkodzenia takie ujawniają się w całym okresie eksploatacji i mają charakter losowy.

Podczas naprawy istnieje możliwość dokładnej oceny stanu technicznego łopatek turbiny. Dotychczas stosowane metody, np.: wizualna, penetracyjna, ultradźwiękowa mają określone możliwości, przez to nie są wystarczająco wiarygodne w procesie oceny wad lub uszkodzeń wewnętrznych, pęknięć podpowierzchniowych itp. Obecnie ocenę stanu technicznego (np. przegrzania) łopatek diagnosta wykonuje metodą wizualną. Decyzję weryfikuje się metodą niszczącą w badaniach metalograficznych $[3,5]$.

Prowadzone są badania nad możliwością zastosowania tomografii komputerowej (CT) do oceny całego spektrum stopów metalicznych, polimerów, kompozytów i materiałów elektronicznych stosowanych w konstrukcjach lotniczych. CT jest szeroko wykorzystywana w przemyśle w procesie kontroli jakości produkcji jako metoda nieniszcząca (NDT). Zastosowanie tej metody do weryfikacji elementów konstrukcji lotniczych wymaga prowadzenia wielu badań, mających na celu potwierdzenie poprawności i wiarygodności otrzymywanych wyników.

Do diagnozowania stanu łopatek wirnikowych niezbędna jest duża dokładność odwzorowania struktury wewnętrznej w celu np. wymiarowania ścianek wewnętrznych, wykrycia wady lub uszkodzenia. Obecnie stosowane urządzenia rentgenowskie pozwalają wykonywać badania tomograficzne $z$ rozdzielczością ok. 0,5 $\mu \mathrm{m}$. Jest to bardzo dobra dokładność w odniesieniu do występujących uszkodzeń, których wymiary są rzędu dziesiątych części milimetra. Prowadzenie badań pojedynczego detalu wymaga pewnego czasu i jest uzależnione od jego rozmiarów, materiału z którego jest wykonany, zadania badawczego, dokładności obróbki wyników itp.

\section{Rentgenowska tomografia komputerowa CT}

Metodą CT można dokonać oceny wielkości uszkodzenia łopatek turbin gazowych, czyli intensywność dekohezji ich materiału. Po wykonaniu prześwietlenia łopatki promieniami rentgenowskimi oraz rekonstrukcji uzyskanych wyników otrzymuje się obrazy przestrzenne. Pozwala to określić i zlokalizować uszkodzenie, jak również wykonać we wszystkich płaszczyznach pomiary geometryczne. W ten sposób możliwe jest określenie jego głębokości, kierunku propagacji oraz prognozowanie możliwości dalszej eksploatacji silnika lotniczego.

Na rysunkach 1 i 2 przedstawiono łopatkę turbiny z wykrytym pęknięciem na krawędzi natarcia oraz pokazano możliwość jego wymiarowania.
Podczas obróbki danych w programie graficznym istnieje możliwość weryfikacji kanałów wewnętrznych łopatek chłodzonych. Uzyskuje się to przez funkcję „przezroczystości”(rys 3, 4).

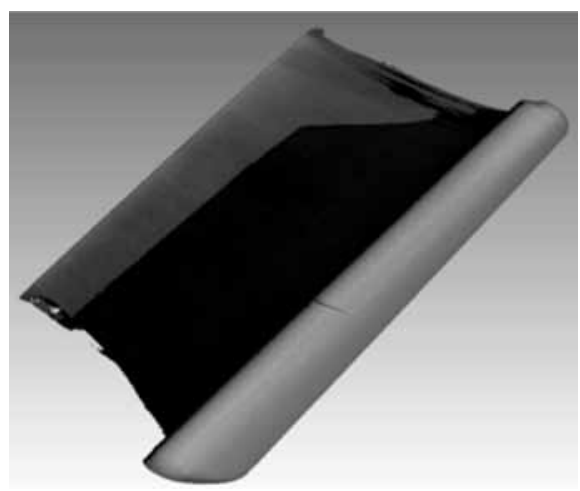

Rys. 1. Pęknięcie na krawędzi natarcia

Fig. 1. Crack on the edge of attack

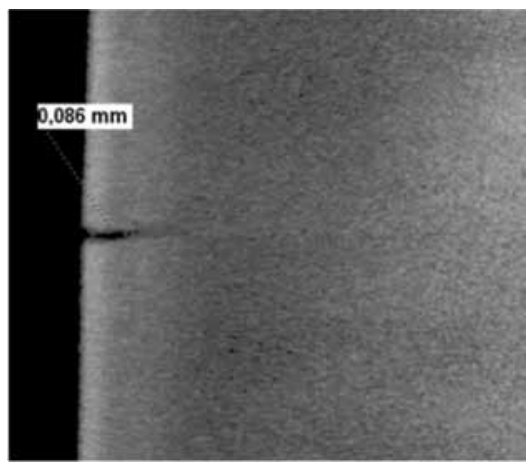

Rys. 2. Zwymiarowane pęknięcie

Fig. 2. Dimensioned crack

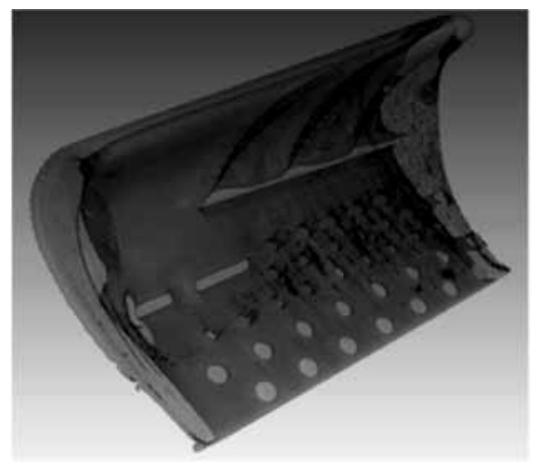

Rys. 3. Zobrazowanie przestrzeni wewnętrznej łopatki turbiny Fig. 3. Illustrating of internal area of a turbine blade

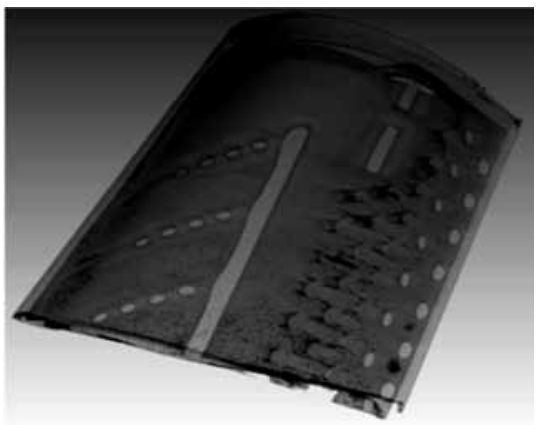

Rys. 4. Zobrazowanie przestrzeni wewnętrznej łopatki turbiny Fig. 4. Illustrating of internal area of a turbine blade 


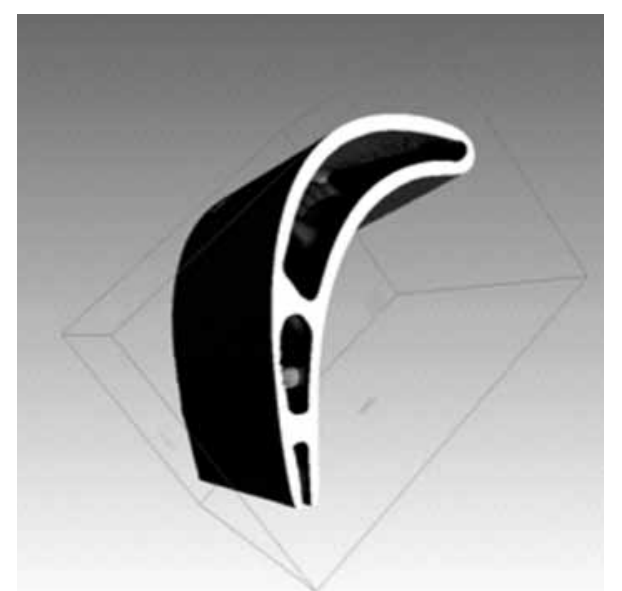

Rys. 5. Przekrój z widokiem wnętrza łopatki

Fig. 5. The blade cross-section with the view of the inner space

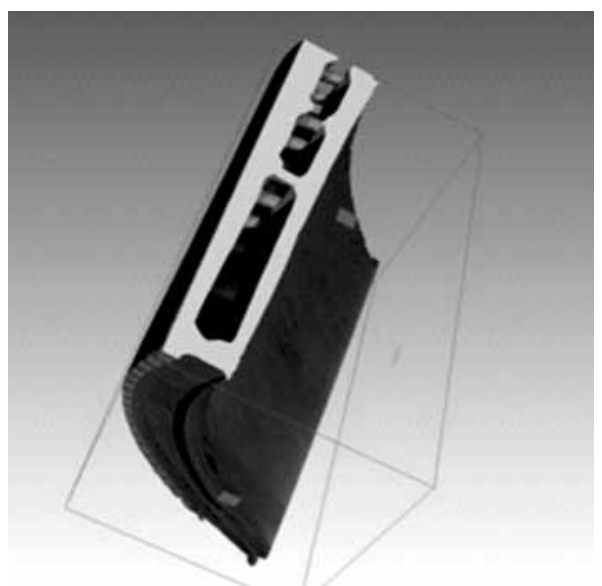

Rys. 6. Przekrój z widokiem wnętrza łopatki

Fig. 6. The blade cross-section with the view of the inner space

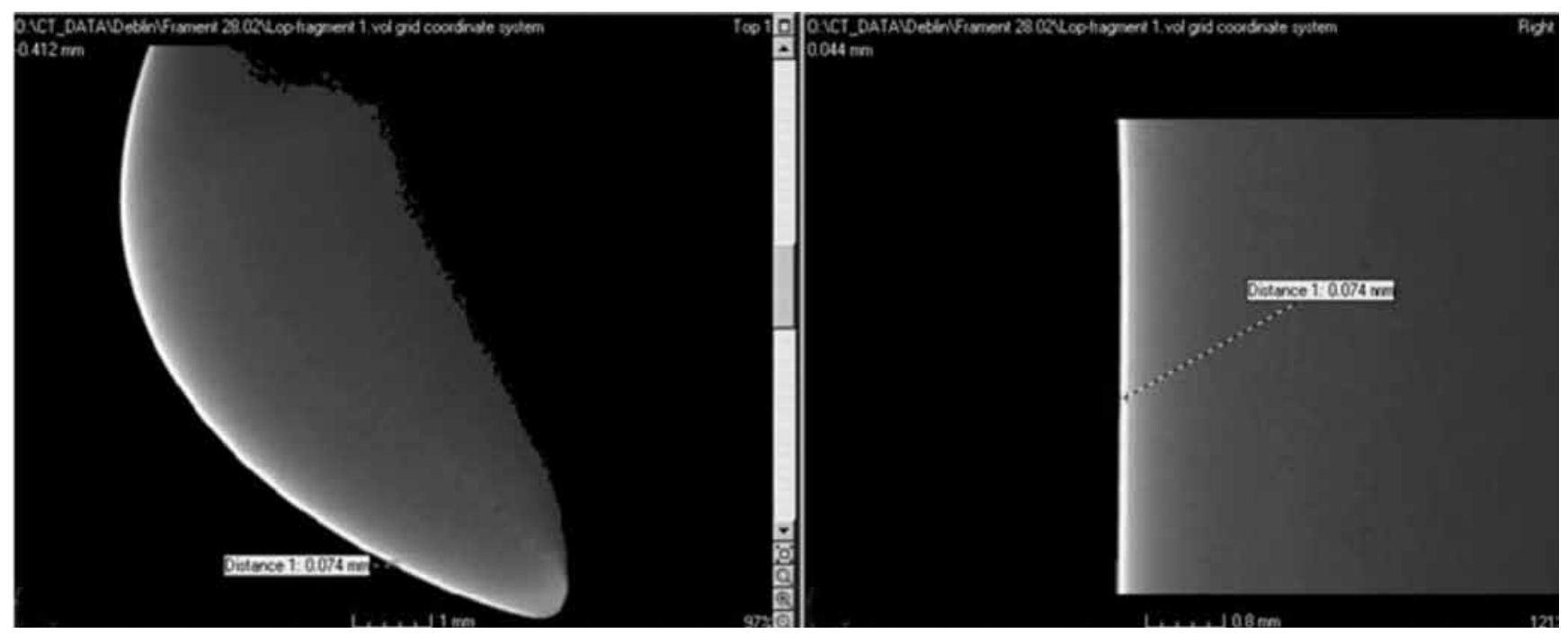

Rys. 7. Widok powłok ochronnych pióra łopatki turbiny oraz przykłady pomiaru ich grubości

Fig. 7. View of protective coatings applied onto a leaf of a turbine blade and examples for measurements of the coating thickness

Podczas analizy obrazów uzyskanych w wyniku badania tomograficznego można dokonywać analizy na poszczególnych głębokościach detalu. Programy do obróbki wyników badań pozwalają „zdejmować” warstwy o zadanej grubości i w ten sposób odsłaniać kolejne głębokości materiału (rys. 5, 6).

Kolejnym zastosowaniem tomografii jest możliwość oceny grubości powłoki ochronnej nakładanej na łopatki turbiny i sprężarki (rys. 7). Na podstawie tych wyników wnioskuje się, że istnieje możliwość określania intensywności zużycia tej powłoki w eksploatacji. Tego rodzaju badania dotychczas były możliwe tylko metodą niszczącą przez wykonanie zgładów metalograficznych.

Tomografia komputerowa umożliwia obserwację rzeczywistych grubości ścianek, także wewnętrznych, niewidocznych. Jest to bardzo istotne w procesie weryfikacji np. odlewów.

Po rekonstrukcji można dokonać pomiarów i automatycznych analiz grubości ścianek. Rozkład grubości można przedstawić graficznie w skali barw, która bezpośrednio pozwala na weryfikację poprawności wykonania łopatki (rys. 8).

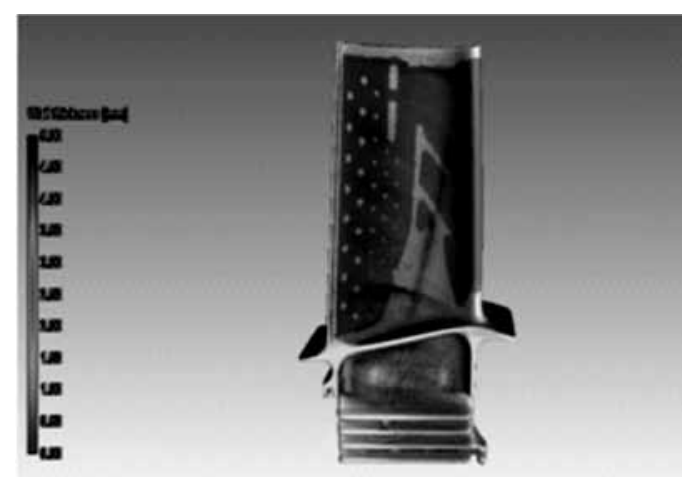

Rys. 8. Obraz grubości powłoki na piórze łopatki turbiny gazowej uzyskany za pomocą tomografu [4]

Fig. 8. View of protective coatings applied onto a leaf of a turbine blade and examples for measurements of the coating thickness 


\title{
Wnioski
}

Proces weryfikacji stanu technicznego łopatek turbin gazowych silników lotniczych, na etapie produkcji, naprawy i eksploatacji, jest bardzo odpowiedzialną operacją. Podstawowa metoda wizualna, wspomagana urządzeniami optycznymi, umożliwia dokonanie oceny stanu na podstawie barwy bądź geometrii pióra łopatki, ale nie umożliwia oceny głębokości uszkodzenia. Jest to szczególnie istotne w przypadku łopatek turbinowych chłodzonych wewnętrznie, ponieważ pęknięcie ścianki na wskroś zmniejsza wytrzymałość łopatki.

Metoda tomografii komputerowej (CT) pozwala w sposób wiarygodny określić wielkość pęknięcia i ocenić intensywność dekohezji materiału łopatki. Zastosowanie metody CT w połączeniu z innymi nieniszczącymi metodami w znacznym stopniu podnosi prawdopodobieństwo wykrycia wady bądź uszkodzenia łopatek turbiny.

Metodę tę można stosować do badań innych elementów konstrukcji lotniczych, jak również całych kompletnych agregatów. Jest to bardzo istotne w przypadku oceny prawidłowości usytuowania poszczególnych detali w urządzeniach, np. agregatach układów sterowania, bezpiecznikach, bądź w układach elektronicznych.

\section{Literatura}

[1] Lewitowicz J.: Podstawy Eksploatacji Statków Powietrznych - Badania Eksploatacyjne Statków Powietrznych; T. 4., ITWL Warszawa 2007.

[2] Szczepanik R., Rządkowski R.: A study on the dynamics of aero engine blades under different operating conditions; ITWL, 2012.

[3] Błachnio J., Spychała J., Pawlak, W., Kułaszka A.: Assessment of technical condition demonstrated by gas turbine blades by processing of images for their surfaces;Journal of KONBIN 1 (21) 2013, s.41-50.
[4] Materiały z firmy YXLON International $\mathrm{GmbH}$.

[5] Lindstedt P.: Parametryczna metoda diagnozowania łopatki pracującej maszyny wirnikowej z eliminacją niemierzalnych czynników otoczenia; Problemy badań i eksploatacji techniki lotniczej. Tom 8; ITWL, 2012.

\section{Badania nieniszczące zestawów kołowych. Zastosowanie różnych metod badań gwarancją poprawnej selekcji zestawów kołowych w trakcie ich naprawy}

\author{
Non-destructive testing of railway wheelsets. \\ Application of various methods of tests as a guarantee of correct sellection \\ of railway wheelsets during repair
}

W artykule zaprezentowano zastosowanie poszczególnych badań na stanowiskach napraw zestawów kołowych wdrożony w ZNTK PATEREK bazując na przepisach krajowych i zagranicznych.

Omówiono zastosowanie różnych metod badań nieniszczących w procesie naprawy lub rewizji zestawów kołowych odgrywających znaczącą rolę oraz będące gwarancją wykrycia jak największej ilości wad zarówno powierzchniowych, jak i objętościowych. Przedstawiono przykłady występowania różnych wad w zestawach kołowych wykrytych różnymi metodami badań.

Opisano związek szkolenia pracowników w zakresie badań nieniszczących w sektorze utrzymania ruchu kolei z doświadczeniem zawodowym i praktycznym w badaniach nieniszczących.
In the article the applications of particular test on repair stands of railway wheelsets in ZNTK PATEREK based on the national and foreign standards were presented.

It was discussed different methods of non-destructive testing carried out during repairs or inspections of wheelsets that play significant role and are guarantee of detection of as many defects as it is possible on the surface and inside of the wheelset.

Examples of occurrence of different defects detected with various methods were presented.

Relation between personnel training in non-destructive testing in railway maintenance sector with professional and practical experience in NDT was described.

Referat wygłoszono podczas 42. KKBN w Kołobrzegu 